\title{
Staple food crops from Brazilian Biofortification Program have high protein quality and hypoglycemic action in Wistar rats
}

\author{
Desirrê Morais DIAS ${ }^{1}$, Mariana Juste Contin GOMES ${ }^{1}$, Maria Eliza de Castro MOREIRA ${ }^{1}$, Dorina NATAL ${ }^{1}$, \\ Roberta Ribeiro SILVA², Marilia NUTTI³, Sérgio Luis da MATTA ${ }^{4}$, Helena Maria Pinheiro SANT’ANA ${ }^{1}$, \\ Hércia Stampini Duarte MARTINO ${ }^{1 *}$ (D)
}

\begin{abstract}
Biofortified staple food crops have become an effective tool by which to address micronutrient deficiencies in many at-risk populations. The effect of these food crops on the micronutrient status has been evaluated, however there is no studies investigating their protein quality, neither by themselves or in a food combination. Thus, this study investigated the effect of combinations of beans and rice, target for biofortification, with high carotenoids content crops (sweet potato and pumpkin) on protein quality, intestinal function and glycemia. Eight groups were evaluated $(\mathrm{n}=6)$ : 1) rice + Caupi bean (RCB); 2) rice + Pontal bean (RPB); 3) rice + Caupi bean + pumpkin (RCBP); 4) rice + Pontal bean + pumpkin (RPBP); 5) rice + Caupi bean + sweet potato (RCBS); 6) rice + Pontal bean + sweet potato (RPBS); 7) casein (positive control); and 8) nitrogen free (negative control). Tested groups showed high protein quality, and groups containing Caupi bean showed higher true digestibility. Groups containing Pontal bean had a greater reduction of blood glucose compared to casein. Tested groups showed higher fecal excretion of lipids. Combination of food target for biofortification showed high protein quality, and the combinations containing Pontal beans showed hypoglycemic effect.
\end{abstract}

Keywords: protein; biofortification; blood glucose; fecal lipid; short chain fatty acids.

Practical Application: The Biofortification program not only provide an additional amount of micronutrient but also contribute to the protein intake of the risk population and potentially improve the glycemic status and intestinal function. Thus, the utilization of these foods may have a positive impact on the nutritional status and health of population at risk for micronutrient deficiency.

\section{Introduction}

Biofortified staple food crops have become an effective tool by which to address micronutrient deficiencies in many at-risk populations (Bouis \& Saltzman, 2017; Dias et al., 2018; Glahn et al., 2017). It aims to improve the micronutrient concentration of staple food crops through the best practices of breeding and modern biotechnology (Bouis et al., 2011; La Frano et al., 2014).

In Brazil, the it has been developed rice, beans, pumpkin and sweet potatoes with higher concentrations of micronutrients (zinc, iron and carotenoids, respectively), using traditional breeding and modern biotechnology (Bouis \& Saltzman, 2017; Nutti et al., 2006). These food crops were chosen because their large production and consumption in Brazil, so they can be largely distribute to the population, especially those at nutritional risk (Bouis \& Saltzman, 2017; Nutti et al., 2006). The iron bioavailability and the efficiency of these foods in improving the nutritional status of iron have been tested in animals (Dias et al., 2015, 2018; Glahn et al., 2017; Tako et al., 2011, 2015) and in humans (Haas et al., 2016; Vaz-Tostes et al., 2016). However, there is no studies about its protein quality, neither by themselves or in a meal.
Some plant foods are sources of protein, however, often present inadequate amounts of essential aminoacids. Although they are not source of high protein quality, these foods contribute significantly to the overall protein intake of the population, they represent the protein sources of lower cost and therefore higher. The combination of different food sources can improve the balance of essential aminoacids and, consequently, protein quality (Cintra et al., 2007; Rezende et al., 2017).

The protein quality of food can be influenced by phytochemicals in foods such as beans, including phytate, tannins and phenolic compounds, which can bind the minerals, proteins and starches, forming insoluble complexes which impair the absorption of these nutrients (Ramírez-Cárdenasi et al., 2008; Rezende et al., 2017). On the other hand, some compounds present in the beans, such as dietary fiber, tannins, phytates and amylase inhibitors have been inversely correlated to the digestion of carbohydrates, glycemic response and the intestinal function (Dias et al., 2018; Hutchins et al., 2012; Pacifici et al., 2017). Also, dietary fiber can improve the lipid metabolism and modulate the intestinal function, since it can reduce fat digestion and absorption, increasing its excretion in feces (Chen et al., 2014). 
There are some studies that evaluated the protein quality in beans (Cruz et al., 2005) and in the combination of rice and bean (Cintra et al., 2007; Kannan et al., 2001). However, there is no studies evaluating the protein quality in combination of biofortified foods, such as beans, rice, pumpkin and sweet potato and its nutritional benefits.

Considering this information, the objective of this study was to evaluate the effect of food combinations of beans and rice, target for biofortification, with high carotenoids content crops (sweet potato and pumpkin) on the protein quality, blood glucose and intestinal modulation.

\section{Materials and methods}

\subsection{Sample}

Since we aimed to evaluate the protein quality and nutritional benefits of biofortified foods, we used the following staple food crops from Brazilian Biofortification Program: common beans (Phaseolus vulgaris L.) BRS Pontal and BRS Xique-Xique (caupi) (high Fe content); white rice (Oryza sativa) Chorinho; pumpkin (Curcubita moscata) Duchesne and sweet potato (Ipomoea batatas) (high pro-vitamin A carotenoid content). Cultivars were developed and supplied by Empresa Brasileira de Pesquisa Agropecuária (EMBRAPA), Brazil.

\subsection{Staple food crop flours preparation}

The common beans were cooked in three replicates in a conventional pressure cooker for 40 minutes using a bean/water ratio of 1:2.2 (w/v) and dried in an air oven for 17 hours at $60^{\circ} \mathrm{C}$ (Ramírez-Cárdenasi et al., 2008). The rice was cooked in three replicates in a conventional cooker using a rice/water ratio of 1:2.8 (w/v) and dried in an air oven for 17 hours at $60^{\circ} \mathrm{C}$. The pumpkin and sweet potato were peeled and sliced on a multiprocessor and dried in an air oven for 6 hours at $60{ }^{\circ} \mathrm{C}$ (Dias et al., 2015). All foods were ground by mill $090 \mathrm{CFT}$ at $3000 \mathrm{rpm}$, sieved (600 mesh screen) and stored at $-12{ }^{\circ} \mathrm{C}$ (Ramírez-Cárdenasi et al., 2008).

\subsection{Chemical composition of foods}

Protein concentration was determined by micro-Kjeldahl method according to the AOAC procedure (Association of Official Analytical Chemists, 2012). The determination of total fiber and soluble and insoluble fractions was performed by the enzymatic-gravimetric method, according to Association of Official Analytical Chemists (2012), using the enzymatic hydrolysis for a heat-resistant amylase, protease, and amyloglucosidase (Total dietary fiber assay Kiyonaga, Sigma ${ }^{\circledR}$ ). The lipid concentration was determined by extraction with ethyl ether using Soxhlet apparatus (Association of Official Analytical Chemists, 2012). The ash concentrations were determined by the gravimetric method based on the weight loss of the materials subjected to heating at $550^{\circ} \mathrm{C}$ (Association of Official Analytical Chemists, 2012). Moisture was determined by drying 10 grams of the samples for 24 hours at $105^{\circ} \mathrm{C}$ in the air oven (Marconi, SP, Brazi) (Association of Official Analytical Chemists, 2012).

\section{Determination of carotenoids}

The extraction of pro-vitamin A carotenoids ( $\alpha$ and $\beta$-carotene) in pumpkin and sweet potato was performed according to Rodriguez et al. (1976). Five grams of the pumpkin and sweet potato flours was ground in $60 \mathrm{~mL}$ of chilled acetone for approximately 2 minutes in a micro grinder and the material was vacuum filtered on Buchner funnel using filter paper. The filtrate was transferred to a separator funnel, in which $50 \mathrm{~mL}$ of cooled petroleum ether were added to transfer the pigment from acetone to petroleum ether. Each fraction was washed three times with distilled water to remove all acetone. The concentration of material was determined by evaporation of the petroleum ether extract using a rotary evaporator at $35^{\circ} \mathrm{C}$. The pigments were re-dissolved in a known amount of petroleum ether and stored in amber glass vials at $-18^{\circ} \mathrm{C}$.

The analyses of carotenoids were performed in triplicate by high performance liquid chromatography (HPLC) using the chromatographic conditions developed by Sant'Ana et al. (1998) as follows: HPLC system (Shimadzu, SCL 10AT VP, Japan) comprised of a high-pressure pump (Shimadzu, LC-10AT VP, Japan), autosampler with $50 \mu \mathrm{L}$ loop (Shimadzu SIL-10AF, Japan) and diode array detector (DAD) (Shimadzu SPD-M10A, Japan); chromatographic column, Phenomenex Gemini RP-18 $(250 \mathrm{~mm} \times 4.6 \mathrm{~mm}, 5 \mu \mathrm{m})$, equipped with a guard column, RP-18 Phenomenex ODS column $(4 \mathrm{~mm} \times 3 \mathrm{~mm})$. The mobile phase was methanol: ethyl acetate: acetonitrile $(80: 10: 10, \mathrm{v} / \mathrm{v} / \mathrm{v})$ at a flow rate of $2.0 \mathrm{~mL} / \mathrm{min}$. Chromatograms were obtained at $450 \mathrm{~nm}$.

\section{Phytate and phenolic compounds}

Phytate content was determined in triplicate by ion exchange and spectrophotometry according to Latta \& Eskin (1980), with modifications by Ellis \& Morris (1986). The determination of the concentration of phenolic compounds in foods was performed using the Folin Ciocalteu reagent as described by (Singleton et al., 1999).

\subsection{Diets}

The composition of the experimental diets were based on AIN-93G diet (Reeves et al., 1993). Replacement of casein diet control the flour of biofortified food was based on food protein content and the contribution of these to the daily protein intake of children aged 7 to 10 years of age, according to research conducted by Hinnig \& Bergamaschi (2012). In this study, it was observed that the bean contribution to the total protein diet consumption was $8.85 \%$, the rice was $4.01 \%$, the pumpkin and sweet potato was $0.35 \%$ each. Thus, based on the amount of protein of these foods it reached a ratio of $50 \%$ of rice, beans $50 \%, 13 \%$ sweet potato and $3 \%$ pumpkin. The composition of the diet was calculated so that the diets were isocaloric and isonitrogenous (Supplementary Material Table S1).

\subsection{Biological assay}

Experiment I: evaluation of protein quality

Forty eight male rats (Rattus norvegicus, Wistar) weaning were randomized into eight groups $(\mathrm{n}=6): 1)$ Rice + Caupi Bean $(\mathrm{RCB}) ; 2)$ Rice + Pontal Bean (RPB); 3) Rice + Caupi Bean + 
Pumpkin (RCBP); 4) Rice + Pontal Bean + Pumpkin (RPBP); 5) Rice + Caupi Bean + Sweet Potato (RCBS); 6) Rice + Pontal Bean + Sweet Potato (RPBS); 7) Positive Control (Casein); 8) Negative Control (no protein) (Figure 1). The animals were kept in individual cages in a room with 12 hours photoperiod and an average temperature of $22^{\circ} \mathrm{C}$ (Figure 1 ).

Food intake and body weight of the animals were recorded weekly. To determine the digestibility diets were labeled with indigo carmine (200 mg. $100 \mathrm{~g} \mathrm{~g}^{-1}$ ) and feces were collected for a period of 4 days. The amount of protein diets, and fecal nitrogen was determined by semi-micro Kjeldahl method. Evaluation of protein quality was determined by Protein Efficiency Ratio (PER) (Association of Official Analytical Chemists, 1975), Net Protein Ratio (NPR) and true digestibility (Amaya et al., 1991).

Experiment II: effects on intestinal function, and modulation of glucose

To evaluate the effect of ingestion of food on the combinations of the modulation of gut function, lipid profile and blood glucose experiment I was extended for further 14 days, keeping the following groups: Rice + Caupi Bean + Pumpkin (RCBP); Rice + Pontal Bean + Pumpkin (RPBP); Rice + Caupi Bean + Sweet Potato (RCBS); Rice + Pontal Bean + Sweet Potato (RPBS); Positive Control (Casein) (Figure 1).

After 28 days and 12 hours fasting, the animals were anesthetized with isoflurane (Isoforine, Cristália ${ }^{\circledR}$ ) were euthanized by cardiac puncture. Blood was collected for the analysis of blood glucose and serum lipids and feces from the cecum were collected for lipid analysis and short-chain fatty acids in the feces. Furthermore, colon fragments were removed and fixed in buffered formalin $10 \%$ solution for histological analysis.

This study was approved by the Ethics Committee for Animal Experimentation of the Federal University of Viçosa, Viçosa, MG.

\subsection{Blood glucose}

Plasma glucose concentrations were determined by colorimetric methods according to the manufacturer's instructions (Bioclin $\left.{ }^{\circledR}\right)$.

\subsection{Short Chain Fatty Acids (SCFA)}

The content of propionic acid, acetic and butyric acids in the feces was determined according to Smiricky-Tjardes et al. (2003) with modifications. The determination of SCFA concentrations in the sample was made in a gas chromatograph (Model GC-2010, Shimadzu Scientific Instruments Inc., Japan). The drug was made through the hydrogen gas stream of $1.8 \mathrm{~mL} / \mathrm{min}$. An initial oven temperature of $100^{\circ} \mathrm{C}$ for 0.5 minutes was used, with subsequent increase of $8{ }^{\circ} \mathrm{C} / \mathrm{min}$ until the temperature of $180{ }^{\circ} \mathrm{C}$ and this was maintained for 1 minute, then increase $20^{\circ} \mathrm{C} / \mathrm{min}$ to $200{ }^{\circ} \mathrm{C}$, which was maintained for 5 minutes. The identification was made by comparison of the retention time, as external standard using a mixture of free short chain fatty acids (free acid Volatile mix codes. 46975, Sigma Aldrich, USA). Quantitation was done by using the standard curve at concentrations from 2 to $10 \mathrm{mM}$.

\subsection{Fecal lipids}

The total lipid content in the feces was determined by extraction using a Soxhlet apparatus, according to the analytical method of Association of Official Analytical Chemists (2012).

I experiment -14 days

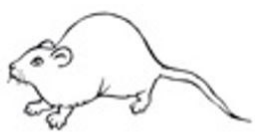

48 male rats (Rattus norvegicus, Wistar) $-\mathrm{n}=6$

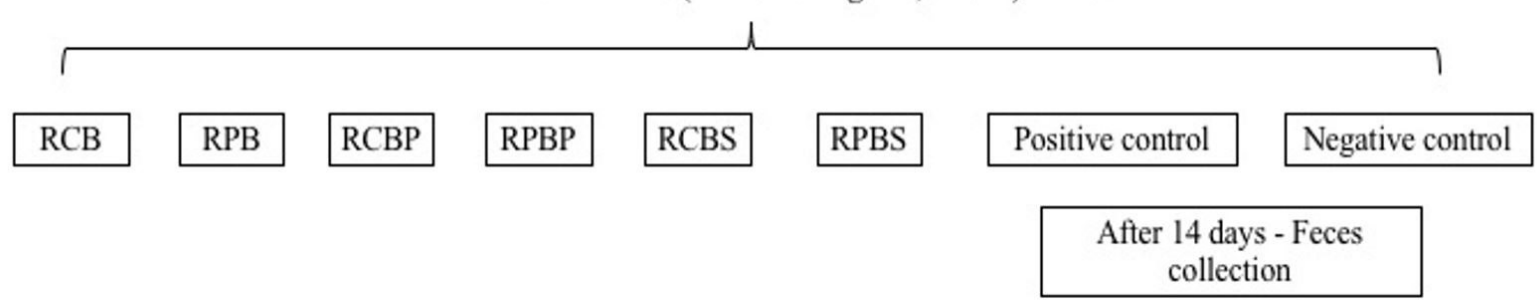

II experiment - more 14 days

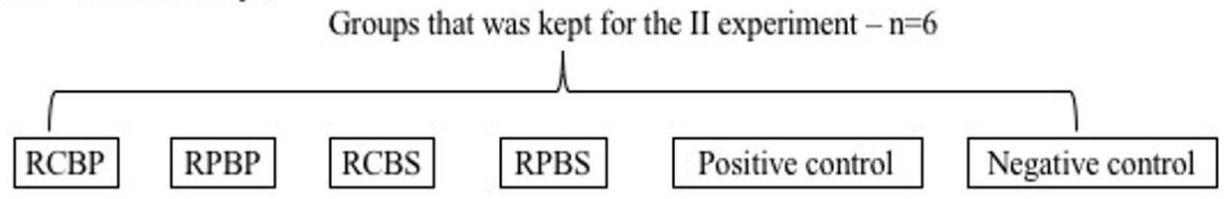

Euthanasia- feces, blood and intestine collection

Figure 1. Scheme showing the experimental design of the study. $\mathrm{RCB}=$ Rice and Caupi Beans; RPB = Rice and Pontal Bean; RCBP = Rice, Caupi Bean and Pumpkin; RPBP = Rice, Pontal Bean and Pumpkin; RCBS = Rice, Caupi Bean and Sweet Potato; RPBS = Rice, Pontal Bean and Sweet Potato. 
In this procedure, extraction was conducted using ethyl ether as solvent.

\subsection{Colon histomorphometric analysis}

Semi-serial histological sections of fragments of the colon of $3 \mathrm{~mm}$ thickness were obtained using automatic microtome (Reichert-Jung ${ }^{\circledR}$, Germany) and were stained by the Toluidine Blue technique. The slides were examined under an Olympus CX31 light microscope. To measure crypt depth (CD) and thickness of the circular and longitudinal muscle layers (CML and LML, respectively), twenty random fields per animal were selected (Silva et al., 2016) and were obtained and analyzed using the ImagePro-Plus ${ }^{\circledR}$ software version 4.5 (Media Cybernetics, Rockville USA).

\subsection{Statistical analysis}

The flours of staple food crops were analyzed in three replicates. The treatments were conducted in a completely randomized design, with six replications. The results were analyzed by analysis of variance. For "F-value" significant, the Newman-Keuls test was used to compare means among the experimental groups. Statistical analyzes was performed using the Statistical Analysis System software, version 9.1. P-value $<0.05$ was considered statistically significance.

\section{Results}

\subsection{Chemical composition of staple food crop flours}

The BRS Pontal flour had the higher total dietary fiber and soluble dietary fiber compared to other foods $(\mathrm{p}<0.05)$ (Table 1$)$. As for the fractions, the pontal beans showed high concentration of soluble dietary fiber (7.04\%) and this result is similar to that found by (Silva et al., 2013) in BRS Pontal raw beans (7.3\%). Pontal bean and caupi bean flours showed similar concentrations ( $p>0.05)$ of phytic acid (Table 2).

\subsection{Effect of the staple food crops on the protein quality}

The experimental groups showed feed efficiency ratio (FER) similar ( $>0.05$ ) (Supplementary Material Table S2), indicating that the diets were isocaloric. The PER and NPR indices of test groups did not differ $(p>0.05)$ of the casein group, indicating high protein quality. Among the test groups it was observed that the RCB and RPBS groups had the lowest $(\mathrm{p}<0.05)$ average of PER and NPR and RPB groups and RPBP showed the highest $(\mathrm{p}<0.05)$ averages for these indices (Table 2).

RCB group, RCBP and RCBS showed higher values of TD and TD-R $(\mathrm{p}<0.05)$ than the other test groups containing pontal beans in their food combinations. Among the test groups the RPBP group showed lowest $(\mathrm{p}<0.05)$ true digestibility (Table 2$)$.

Table 1. Chemical composition of flours food inserted in the biofortification program, on dry basis (g/100 g).

\begin{tabular}{lccrrr}
\hline & Caupi Bean & Pontal Bean & Rice & Pumpkin & Sweet Potato \\
\hline Moisture & $8.27^{\mathrm{c}} \pm 0.1$ & $10.7^{\mathrm{a}} \pm 0.28$ & $7.35^{\mathrm{d}} \pm 0.06$ & $9.99^{\mathrm{ab}} \pm 0.55$ & $9.92^{\mathrm{b}} \pm 0.06$ \\
Ash & $2.93^{\mathrm{c}} \pm 0.02$ & $3.14^{\mathrm{b}} \pm 0.03$ & $0.34^{\mathrm{e}} \pm 0.02$ & $6.38^{\mathrm{a}} \pm 0.07$ & $2.27^{\mathrm{d}} \pm 0.06$ \\
Lipids & $2.23^{\mathrm{a}} \pm 0.22$ & $1.37^{\mathrm{b}} \pm 0.3$ & $0.13^{\mathrm{c}} \pm 0.13$ & $1.46^{\mathrm{b}} \pm 0.14$ & $1.55^{\mathrm{e}} \pm 0.34$ \\
Protein & $23.15^{\mathrm{a}} \pm 0.32$ & $18.86^{\mathrm{b}} \pm 0.08$ & $8.83^{\mathrm{d}} \pm 0.18$ & $15.86^{\mathrm{c}} \pm 0.24$ & $2.63^{\mathrm{e}} \pm 0.12$ \\
Total dietary fiber & $15.53^{\mathrm{b}} \pm 0.92$ & $26.69^{\mathrm{a}} \pm 0.45$ & $1.08^{\mathrm{c}} \pm 0.1$ & $15.02^{\mathrm{b}} \pm 0.03$ & $15.31^{\mathrm{b}} \pm 0.31$ \\
Soluble fiber & $1.88^{\mathrm{b}} \pm 0.11$ & $7.04^{\mathrm{a}} \pm 1.27$ & $0.37^{\mathrm{b}} \pm 0.08$ & $5.10^{\mathrm{a}} \pm 0.25$ & $4.89^{\mathrm{a}} \pm 0.63$ \\
Insoluble fiber & $13.66^{\mathrm{b}} \pm 0.82$ & $19.64^{\mathrm{a}} \pm 0.92$ & $0.87^{\mathrm{d}} \pm 0.43$ & $9.92^{\mathrm{c}} \pm 0.23$ & $10.42^{\mathrm{c}} \pm 0.38$ \\
Carbohydrates & $48.87^{\mathrm{bc}} \pm 0,73$ & $48.87^{\mathrm{bc}} \pm 0.73$ & $82.48^{\mathrm{a}} \pm 0.05$ & $52.19^{\mathrm{bc}} \pm 0.34$ & $69.62^{\mathrm{ac}} \pm 0.56$ \\
Total phenolic (mg/100 g) & $89.0^{\mathrm{c}} \pm 0,09$ & $133^{\mathrm{b}} \pm 0.15$ & $6^{\mathrm{d}} \pm 0.01$ & $241^{\mathrm{a}} \pm 0.12$ & $151^{\mathrm{b}} \pm 0.07$ \\
Carotenoids (mg/100 g) & nd & nd & nd & $308.84^{\mathrm{a}} \pm 1.98$ & $127.11^{\mathrm{b}} \pm 0.06$ \\
Phytic acid & $0.54^{\mathrm{a}} \pm 0.01$ & $0.51^{\mathrm{a}} \pm 0.02$ & $0.20^{\mathrm{b}} \pm 0.03$ & $0.03^{\mathrm{c}} \pm 0.32$ & $0.10^{\mathrm{c}} \pm 0.1$ \\
\hline
\end{tabular}

Data presented as mean and standard deviation. nd $=$ not determined. Means with different letters in the same line present significant difference $(p<0.05)$ by Tukey test. ${ }^{*}$ BIOFORT/ HarvestPlus.

Table 2. Effect of the staple food crops intake on the protein quality.

\begin{tabular}{|c|c|c|c|c|c|c|}
\hline & PER & PER-R & NPR & NPR-R & $\mathrm{TD}$ & TD-R \\
\hline Casein & $3.43^{a} \pm 0.74$ & $100^{a}$ & $4.08^{a} \pm 0.71$ & $100^{\mathrm{a}}$ & $94.24^{\mathrm{a}} \pm 1.32$ & $100^{\mathrm{a}}$ \\
\hline RCB & $2.75^{\mathrm{b}} \pm 0.36$ & $80.3^{\mathrm{b}} \pm 14.37$ & $3.39^{c} \pm 0.5$ & $83.11^{\mathrm{c}} \pm 12.47$ & $81.51^{\mathrm{a}} \pm 3.05$ & $86.5^{\mathrm{a}} \pm 3.23$ \\
\hline RPB & $3.33^{\mathrm{a}} \pm 0.3$ & $97.02^{\mathrm{a}} \pm 8.84$ & $4.22^{\mathrm{a}} \pm 0.27$ & $103.38^{c} \pm 6.61$ & $74.58^{\mathrm{b}} \pm 4.55$ & $79.13^{b} \pm 4.83$ \\
\hline RCBP & $3.11^{\mathrm{a} b} \pm 0.39$ & $90.63^{\mathrm{ab}} \pm 11.4$ & $3.84^{\mathrm{abc}} \pm 0.45$ & $94.09^{\mathrm{abc}} \pm 11.17$ & $79.53^{\mathrm{ab}} \pm 2.65$ & $84.39^{\mathrm{ab}} \pm 2.81$ \\
\hline RPBP & $3.30^{\mathrm{a}} \pm 0.36$ & $96.28^{a} \pm 10.66$ & $4.14^{\mathrm{ab}} \pm 0.38$ & $101.34^{\mathrm{ab}} \pm 9.3$ & $73.35^{\mathrm{c}} \pm 2.05$ & $77.83^{c} \pm 2.17$ \\
\hline RCBS & $3.14^{\mathrm{ab}} \pm 0.42$ & $91.45^{\mathrm{ab}} \pm 12.25$ & $3.98^{\mathrm{abc}} \pm 0.51$ & $97.43^{\mathrm{abc}} \pm 12.48$ & $83.03^{\mathrm{a}} \pm 6.47$ & $87^{\mathrm{a}} \pm 5.59$ \\
\hline RPBS & $2.69^{\mathrm{b}} \pm 0.43$ & $78.48^{\mathrm{b}} \pm 12.79$ & $3.62^{b c} \pm 0.47$ & $88.76^{b c} \pm 11.62$ & $75.16^{\mathrm{bc}} \pm 4.14$ & $79.75^{b c} \pm 4.39$ \\
\hline
\end{tabular}

Data presented as mean and standard deviation. RCB = Rice and Caupi Beans; RPB = Rice and Pontal Bean; RCBP = Rice, Caupi Bean and Pumpkin; RPBP = Rice, Pontal Bean and Pumpkin; RCBS = Rice, Caupi Bean and Sweet Potato; RPBS = Rice, Pontal Bean and Sweet Potato; PER = protein efficiency quotient; PER-R = Relative PER; NPR = net protein ratio; NPR-R = Relative NPR; TD = true digestibility; TD-R = relative true digestibility. Means with lower case in the same columns present significant difference by the Newman-Keuls test $(\mathrm{p}<0.05) . \mathrm{n}=6$, period of 14 day. 


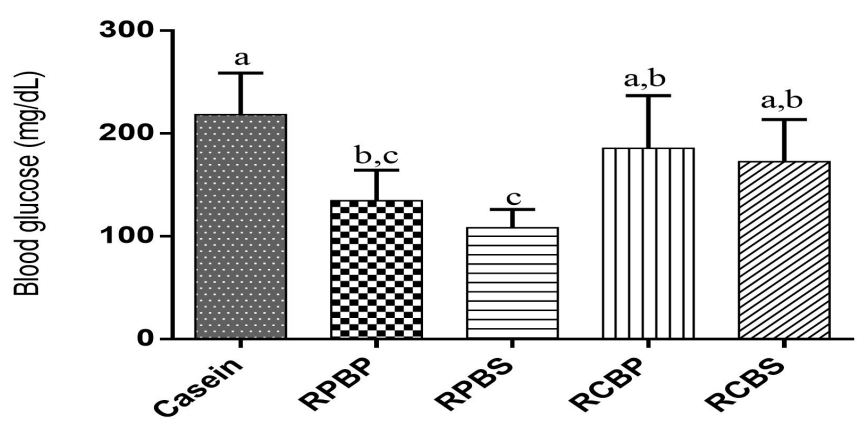

Figure 2. Blood glucose of animals fed casein and diets containing biofortified food combinations $(n=6)$, period of 28 days. RPBP $=$ Rice + Pontal Bean + Pumpkin; RPBS = Rice + Pontal Bean + Sweet Potato; $\mathrm{RCBP}=$ Rice + Caupi Bean + Pumpkin; RCBS $=$ Rice + Caupi Bean + Sweet Potato. Different letters indicate significant difference by the Newman-Keuls test $(\mathrm{p}<0.05)$.

\subsection{Effect of the staple food crops intake on the blood glucose}

Animals fed diets with food combinations containing pontal beans, RPBP and RPBS, had lower blood glucose concentrations $(\mathrm{p}<0.05)$ than animals fed the control diet (Figure 2$)$. That effect could be related to the higher soluble fiber content in the pontal bean (Table 1).

\subsection{Effect of the staple food crops intake on the intestinal modulation}

The control group and the RPBP group showed higher crypt depth $(\mathrm{p}<0.05)$ and longitudinal muscle layer than the other test groups (RPBS, RCBP, RCBS) (Table 3 and Figure 3 ).

The excretion of fecal fat of animals fed diets containing combinations of test foods was higher $(p<0.05)$ than the animals
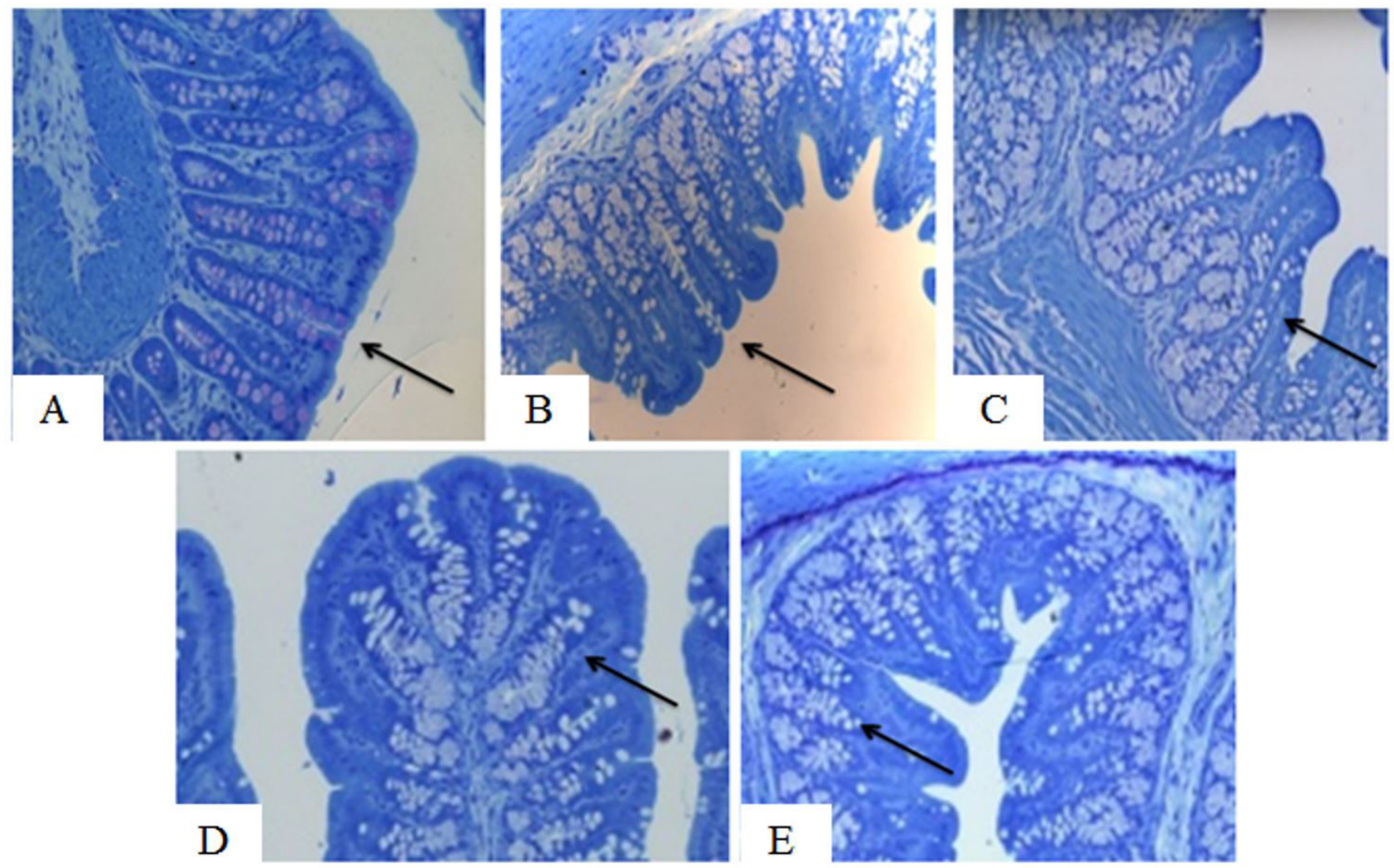

Figure 3. Sections of colon indicating crypt depth in rats fed with different combinations of basic food products and casein. The arrows indicate the intestinal crypts. Toluidine blue, 10x. (A) Casein; (B) RPBA; (C) RPBS; (D) RCBP; (E) RCBS.

Table 3. Effect of staple food crops intake on gut morphometry of Wistar rats.

\begin{tabular}{clcc}
\hline & Crypt Depth & Middle Muscle Layer & Longitudinal Muscle Layer \\
\hline Control & $167.67^{\mathrm{A}} \pm 23.07$ & $44.44^{\mathrm{A}} \pm 7.46$ & $140.84^{\mathrm{A}} \pm 14.16$ \\
RPBP & $151.82^{\mathrm{a}} \pm 4$ & $33.94^{\mathrm{a}} \pm 4.59$ & $126.25^{\mathrm{a}} \pm 6.19$ \\
RPBS & $130.45^{\mathrm{b}} \pm 6.71$ & $36.77^{\mathrm{a}} \pm 7.37$ & $110.45^{\mathrm{a}} \pm 12.08$ \\
RCBP & $133.57^{\mathrm{b}} \pm 11.04$ & $39.04^{\mathrm{a}} \pm 3.76$ & $109.21^{\mathrm{a}} \pm 7.13$ \\
RCBS & $132.28^{\mathrm{b}} \pm 15.94$ & $41.61^{\mathrm{a}} \pm 6.76$ & $121.83^{\mathrm{a}} \pm 10.11$ \\
\hline
\end{tabular}

Data presented as mean and standard deviation. RPBP $=$ Rice, Pontal Bean and Pumpkin; RPBS = Rice, Pontal Bean and Sweet Potato; RCBP $=$ Rice, Caupi Bean and Pumpkin; RCBS = Rice,

Caupi Bean and Sweet Potato; Results in $\mu \mathrm{m}$. Means with lower case in the same columns present significant difference by the Newman-Keuls test ( $\mathrm{p}<0.05$ ). $\mathrm{n}=6$, period of 14 days. 

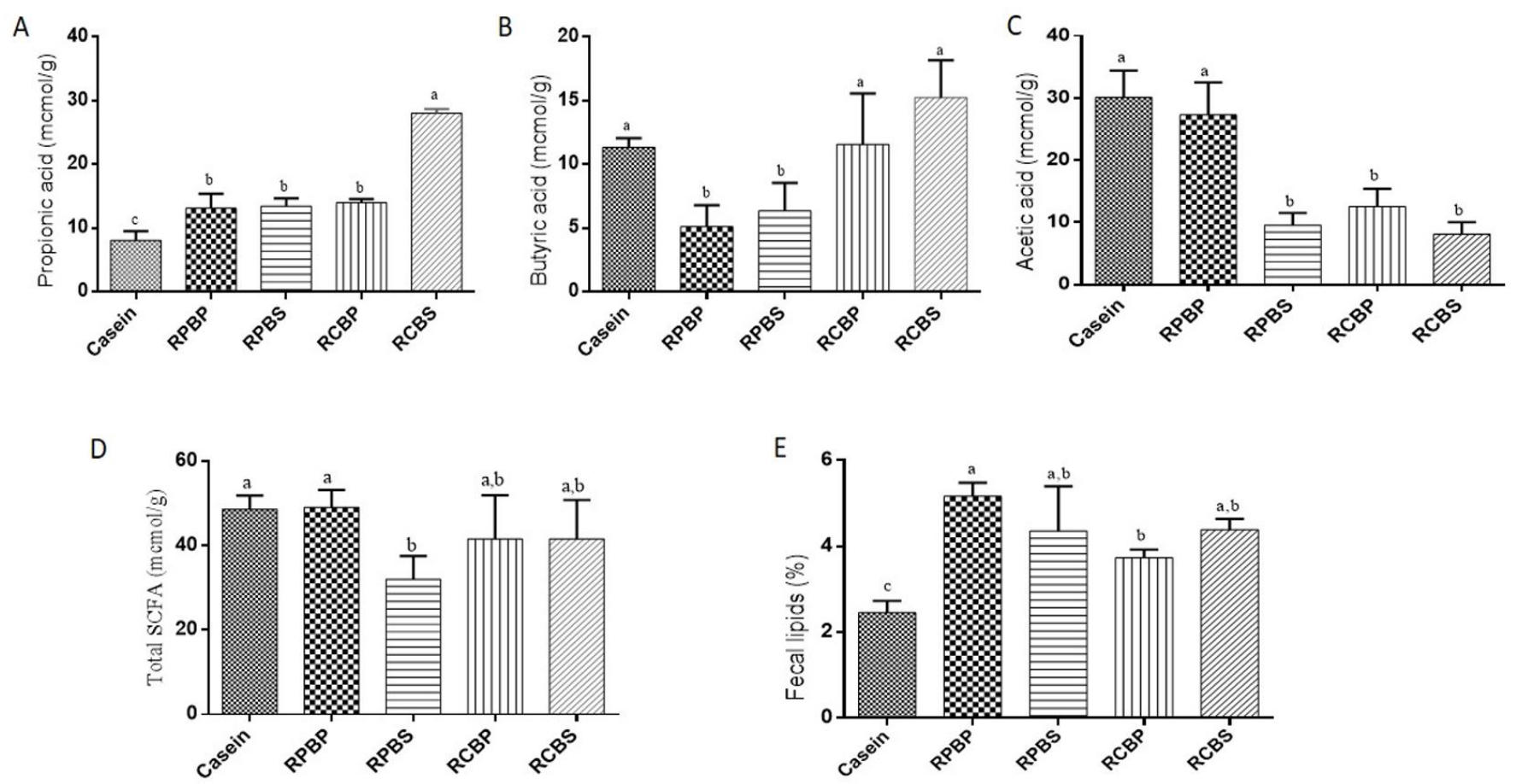

Figure 4. Concentration of short chain fatty acids (SCFA) and fecal fat excretion in feces of animals fed casein and diets containing biofortified food combinations $(n=6)$, period of 28 days. (A) Propionic acid; (B) Butyric acid; (C) Acetic acid; (D) Total SCFA; (E) Total fecal lipid. RPBP = Rice + Pongal Bean + Pumpkin; RPBS $=$ Rice + Pontal Bean + Sweet Potato RCBP $=$ Rice + Caupi Bean + Pumpkin; RCBS $=$ Rice + Caupi Bean + Sweet Potato. Different letters indicate significant difference by the Newman-Keuls test $(\mathrm{p}<0.05)$.

receiving the control diet (casein) (Figure 4E). Among the test groups, the RCBP group showed the lowest $(\mathrm{p}<0.05)$ fecal fat excretion (Figure 4E). Furthermore, the RPBP group showed high $(\mathrm{p}<0.05)$ acetate concentration in the feces (Figure $4 \mathrm{C})$.

\section{Discussion}

This study evaluated the effect of food combinations of beans and rice, target for biofortification, with high carotenoids content crops (sweet potato and pumpkin) on the protein quality, blood glucose and intestinal modulation in rats. The results showed that the all experimental groups presented a similar feed efficiency ratio (FER) (Supplementary Material Table S2), indicating that the diets were isocaloric. The PER and NPR indices of test groups did not differ of the casein group, indicating high protein quality. Among test groups it was observed that the RCB and RPBS groups had the lowest average of PER and NPR and RPB groups and RPBP showed the highest averages for these indices (Table 2). Thus, the combination of different plants studied, such as a cereal, a legume and a vegetable resulted in PER and NPR values similar to those of casein, indicating high biological value of the protein combinations.

RCB group, RCBP and RCBS showed higher values of TD and TD-R than the other test groups containing pontal beans in their combinations. Among the test groups the RPBP group showed lowest true digestibility (Table 2 ). The higher digestibility found in the groups containing caupi bean may be associated with lower contents of soluble dietary fiber and phenolic compounds compared to pontal beans. The soluble dietary fiber can form complexes in the intestinal content, prevent access of digestive enzymes, reducing protein digestibility (Kendall et al., 2010).

Animals fed with diets containing pontal beans, RPBP and RPBS, had lower blood glucose concentrations than animals fed with the control diet (Figure 2). This result may be associated with the content of dietary fiber, especially the soluble fraction, present in pontal beans which was higher than the caupi bean. The soluble fiber slows the glucose contact with the intestinal absorptive area, thereby reducing its absorption. Moreover, the fibers may increase peripheral insulin sensitivity (Aleixandre \& Miguel, 2016; Stewart \& Zimmer, 2018).

Furthermore, the RPBP group showed high acetate concentration in feces. The acetate can reduce the blood glucose by activating hepatic AMPK pathway which reduce expression of gluconeogenesis enzymes (Sakakibara et al., 2006). Another factor that may have contributed to the difference in blood glucose between the groups is the fact that these two groups showed lower concentrations of butyric acid in the feces (Figure 4B). The butyrate may increase the gene expression of GLUT2 in intestinal cells (Andrade et al., 2013; Chen et al., 2014), increased glucose uptake and thus leading to increased blood glucose levels.

The control group and the RPBP group showed higher crypt depth and longitudinal muscle layer than the other test groups (RPBS, RCBP, RCBS) (Table 3 and Figure 3). Conversely, Andrade et al. (2013) observed an increased thickness of the 
muscle layers of the intestine of animals fed soy compared to animals fed casein. The result of this study may be related to higher total concentration of SCFA (Figure 4D) present in animal feces of control and RPBP group compared to other groups. It is known that SCFAs may modulate the proliferation of intestinal cells, increasing the crypt depth and intestinal muscle layer (Nilsson et al., 2013). Moreover, the control group received cellulose as dietary fiber source, and this carbohydrate has the ability to stimulate proliferation of intestinal cells (Rezaei et al., 2014).

The excretion of fecal fat of animals fed diets containing combinations of test foods was higher than the animals receiving the control diet (casein). Among the test groups, the RCBP group showed the lowest fecal fat excretion (Figure 4E). The increased excretion of fecal fat may be related to the high content of soluble dietary fiber present in the food testing. Soluble fiber slows digestion and absorption of fat, thereby increasing its excretion in the feces (Cherem \& Bramosrki, 2008). Moreover, Marques et al. (2015) in an in vitro study showed that caupi bean peptides were able to inhibit the HMG-CoA reductase and reduce the micellar solubilization of cholesterol, thereby increasing the fecal excretion of lipids. The rice peptides can bind to bile acids and reduce its availability for micelle formation, thus reducing the micellar lipid transport and increasing their fecal excretion (Cam \& De Mejia, 2012). Thus, these results show that the combination of food target for biofortification presents high protein quality, and the combinations containing Pontal beans can promote a reduction in the blood glucose, hence it can present a hypoglycemic effect.

\section{Conclusion}

The combination of beans and rice, and these with biofortified pumpkin and sweet potato presented PER and NPR indices similar to control group, indicating high protein quality. The combination of pontal bean and pumpkin flours increased the total concentration of SCFA in the feces and the intestinal crypt depth compared to the other groups, which suggests an improvement in the intestinal function. Moreover, all food combinations increased fecal excretion of lipids, and combinations containing the pontal beans showed hypoglycemic action.

Overall, our results indicate that the foods from the Biofortification program not only provide an additional amount of micronutrient but it can also contribute to the protein intake of the risk population and potentially improve the glycemic status and intestinal function. Thus, the utilization of these foods may have a positive impact on the nutritional status and health of population at risk for micronutrient deficiency.

\section{Acknowledgements}

The authors would like to thank the Embrapa (Brazil) and Foundation for Research Support of Minas Gerais (FAPEMIG APQ-00546-12, Brazil) for the research financial support; the Coordination for the Improvement of Higher Education Personnel (CAPES, Brazil), and the National Cousel of Technological and Scientific Development (CNPq, Brazil) for the Master's and the scientific initiation's fellowships, respectively.

\section{References}

Aleixandre, A., \& Miguel, M. (2016). Dietary fiber and blood pressure control. Food \& Function, 7(4), 1864-1871. http://dx.doi.org/10.1039/ C5FO00950B. PMid:26923351.

Amaya, H., Acevedo, E., \& Bressani, R. (1991). Efecto del recalentamiento sobre la disponibilidad de hierro y el valor nutritivo de la proteina del frijol negro (Phaseolus vulgaris) cocido. Archivos Latinoamericanos de Nutricion, 41(2), 222-237. PMid:1811452.

Andrade, G., Almeida, C., Espeschit, A., Dantas, M. I., Benjamin, L., Ribeiro, S., \& Martino, H. (2013). The addition of whole soy flour to cafeteria diet reduces metabolic risk markers in wistar rats. Lipids in Health and Disease, 12(1), 145. http://dx.doi.org/10.1186/1476511X-12-145. PMid:24119309.

Association of Official Analytical Chemists - AOAC. (1975). Official methods of analysis of the Association of Official Analytical Chemists (19th ed). Gaithersburg: AOAC.

Association of Official Analytical Chemists - AOAC. (2012). Appendix J: AOAC International methods committee guidelines for validation of microbiological methods for food and environmental surfaces (pp. 1-21). Gaithersburg: AOAC.

Bouis, H. E., \& Saltzman, A. (2017). Improving nutrition through biofortification: a review of evidence from HarvestPlus, 2003 through 2016. Global Food Security, 12, 49-58. http://dx.doi.org/10.1016/j. gfs.2017.01.009. PMid:28580239.

Bouis, H. E., Hotz, C., McClafferty, B., Meenakshi, J. V., \& Pfeiffer, W. H. (2011). Biofortification: a new tool to reduce micronutrient malnutrition. Improving Diets and Nutrition: Food-Based Approaches, 32(1, Suppl.), 202-215. http://dx.doi.org/10.1079/9781780642994.0202. PMid:21717916.

Cam, A., \& De Mejia, E. G. (2012). Role of dietary proteins and peptides in cardiovascular disease. Molecular Nutrition \& Food Research, 56(1), 53-66. http://dx.doi.org/10.1002/mnfr.201100535. PMid:22121103.

Chen, K. H., Dasgupta, A., Ding, J., Indig, F. E., Ghosh, P., \& Longo, D. L. (2014). Impact of dietary fiber-based SCFA mixtures on colon epithelial barrier function. The FASEB Journal, 28(1), 382-394. http:// dx.doi.org/10.1096/fj.13-230037. PMid:24081906.

Cherem, R. A., \& Bramosrki, A. (2008). Excreção de gordura fecal de ratos (Rattus norvegicus, Wistar), submetidos a dietas hiperlipídicas e hipercolesterolêmicas suplementadas com quitosana. Revista Brasileira de Ciências Farmacêuticas, 44(4), 701-706. http://dx.doi. org/10.1590/S1516-93322008000400017.

Cintra, R. M. G. C., Magalhães, C. O., Garcia, R. R., Mello, R., Padilha, A., Kusai, C., \& Caetano, L. (2007). Avaliação da qualidade da proteína de arroz e feijão e de dieta da região sudeste do brasil. Alimentos e Nutrição, 18(3), 283-289.

Cruz, G. A. D. R., Oliveira, M. G. A., Costa, N. M. B., Pires, C. V., Cruz, R. S., \& Moreira, M. A. (2005). Comparação entre a digestibilidade proteica in vitro e in vivo de diferentes cultivares de feijão (Phaseolus vulgaris L.) armazenados por 30 dias. Alimentos e Nutrição, 16(3), 265-271.

Dias, D. M., Castro Moreira, M. E., Gomes, M. J. C., Toledo, R. C. L., Nutti, M. R., Sant'Ana, H. M. P., \& Martino, H. S. D. (2015). Rice and bean targets for biofortification combined with high carotenoid content crops regulate transcriptional mechanisms increasing iron bioavailability. Nutrients, 7(11), 9683-9696. http://dx.doi.org/10.3390/ nu7115488. PMid:26610564.

Dias, D. M., Kolba, N., Binyamin, D., Ziv, O., Nutti, M. R., Martino, H. S. D., Glahn, R. P., Koren, O., \& Tako, E. (2018). Iron biofortified carioca bean (Phaseolus vulgaris L.) based brazilian diet delivers more absorbable iron and affects the gut microbiota in vivo (Gallus 
gallus). Nutrients, 10(12), 1-20. http://dx.doi.org/10.3390/nu10121970. PMid:30551574.

Ellis, R., \& Morris, E. R. (1986). Appropriate resin selection for rapid phytate analysis by ion-exchange chromatography. Cereal Chemistry, 63(1), 58-59.

Glahn, R., Tako, E., Hart, J., Haas, J., Lung'aho, M., \& Beebe, S. (2017). Iron bioavailability studies of the first generation of iron-biofortified beans released in Rwanda. Nutrients, 9(7), 787. http://dx.doi. org/10.3390/nu9070787. PMid:28754026.

Haas, J. D., Luna, S. V., Lung’aho, M. G., Wenger, M. J., Murray-Kolb, L. E., Beebe, S., Gahutu, J. B., \& Egli, I. M. (2016). Consuming iron biofortified beans increases iron status in Rwandan women after 128 days in a randomized controlled feeding trial. The Journal of Nutrition, 146(8), 1586-1592. http://dx.doi.org/10.3945/jn.115.224741. PMid:27358417.

Hinnig, P. F., \& Bergamaschi, D. P. (2012). Itens alimentares no consumo alimentar de crianças de 7 a 10 anos. Revista Brasileira de Epidemiologia, 15(2), 324-334. http://dx.doi.org/10.1590/S1415790X2012000200010. PMid:22782098.

Hutchins, A. M., Winham, D. M., \& Thompson, S. V. (2012). Phaseolus beans: impact on glycaemic response and chronic disease risk in human subjects. British Journal of Nutrition, 108(Suppl. 1), S52-S65. http://dx.doi.org/10.1017/S0007114512000761. PMid:22916816.

Kannan, S., Nielsen, S. S., \& Mason, A. C. (2001). Protein digestibilitycorrected amino acid scores for bean and bean: rice infant weaning food products. Journal of Agricultural and Food Chemistry, 49(10), 5070-5074. http://dx.doi.org/10.1021/jf010323u. PMid:11600068.

Kendall, C. W., Esfahani, A., \& Jenkins, D. J. (2010). The link between dietary fibre and human health. Food Hydrocolloids, 24(1), 42-48. http://dx.doi.org/10.1016/j.foodhyd.2009.08.002.

La Frano, M. R., Moura, F. F., Boy, E., Lönnerdal, B., \& Burri, B. J. (2014). Bioavailability of iron, zinc, and provitamin A carotenoids in biofortified staple crops. Nutrition Reviews, 72(5), 289-307. http:// dx.doi.org/10.1111/nure.12108. PMid:24689451.

Latta, M., \& Eskin, M. (1980). A simple and rapid colorimetric method for phytate determination. Journal of Agricultural and Food Chemistry, 28(6), 1313-1315. http://dx.doi.org/10.1021/jf60232a049.

Marques, M. R., Freitas, R. A. M. S., Carlos, A. C. C., Siguemoto, É. S., Fontanari, G. G., \& Arêas, J. A. G. (2015). Peptides from cowpea present antioxidant activity, inhibit cholesterol synthesis and its solubilisation into micelles. Food Chemistry, 168, 288-293. http:// dx.doi.org/10.1016/j.foodchem.2014.07.049. PMid:25172712.

Nilsson, A., Johansson, E., Ekström, L., \& Björck, I. (2013). Effects of a brown beans evening meal on metabolic risk markers and appetite regulating hormones at a subsequent standardized breakfast: a randomized cross-over study. PLoS One, 8(4), e59985. http://dx.doi. org/10.1371/journal.pone.0059985. PMid:23577078.

Nutti, M., Carvalho, J. L. V., \& Watanabe, E. (2006). A biofortificação como ferramenta para combate a deficiências em micronutrientes. Rio de Janeiro: Embrapa Agroindústria de Alimentos.

Pacifici, S., Song, J., Zhang, C., Wang, Q., Glahn, R. P., Kolba, N., \& Tako, E. (2017). Intra amniotic administration of raffinose and stachyose affects the intestinal brush border functionality and alters gut microflora populations. Nutrients, 9(3), 304. http://dx.doi. org/10.3390/nu9030304. PMid:28335485.

Ramírez-Cárdenasi, L., Leonel, A. J., \& Costa, N. M. B. (2008). Efeito do processamento doméstico sobre o teor de nutrientes e de fatores antinutricionais de diferentes cultivares de feijão comum. Food
Science and Technology (Campinas), 28(1), 200-213. http://dx.doi. org/10.1590/S0101-20612008000100029.

Reeves, P. G., Nielsen, F. H., \& Fahey, J. G. C. Jr. (1993). AIN-93 purified diets for laboratory rodents: final report of the American Institute of Nutrition ad hoc writing committee on the reformulation of the AIN-76A rodent diet. The Journal of Nutrition, 123(11), 1939-1951. http://dx.doi.org/10.1093/jn/123.11.1939. PMid:8229312.

Rezaei, M., Torshizi, M., \& Shariatmadari, F. (2014). Inclusion of processed rice hulls as insoluble fiber in the diet on performance and digestive traits of Japanese quails. Journal of Animal Science Advances, 4(7), 962-972. http://dx.doi.org/10.5455/jasa.20140724124546.

Rezende, A. A., Pacheco, M. T. B., Silva, V. S. N., \& Ferreira, T. A. P. C. (2017). Nutritional and protein quality of dry Brazilian beans (Phaseolus vulgaris L.). Food Science and Technology, 38(3), 421-427. http://dx.doi.org/10.1590/1678-457x.05917.

Rodriguez, D. B., Raymundo, L. C., Lee, T. C., Simpson, K. L., \& Chichester, C. O. (1976). Carotenoid pigment changes in ripening Momordica charantia fruits. Annals of Botany, 40(3), 615-624. http:// dx.doi.org/10.1093/oxfordjournals.aob.a085171.

Sakakibara, S., Yamauchi, T., Oshima, Y., Tsukamoto, Y., \& Kadowaki, T. (2006). Acetic acid activates hepatic AMPK and reduces hyperglycemia in diabetic KK-A(y) mice. Biochemical and Biophysical Research Communications, 344(2), 597-604. http://dx.doi.org/10.1016/j. bbrc.2006.03.176. PMid:16630552.

Sant'Ana, H. M. P., Stringheta, P. C., Brandão, S. C. C., \& Azeredo, R. M. C. (1998). Carotenoid retention and vitamin A value in carrot (Daucus carota L. ) prepared by food service. Food Chemistry, 61(12), 145-151. http://dx.doi.org/10.1016/S0308-8146(97)00084-8.

Silva, B. P., Dias, D. M., Castro Moreira, M. E., Toledo, R. C. L., Matta, S. L. P., Lucia, C. M. D., Martino, H. S. D., \& Pinheiro-Sant'Ana, H. M. (2016). Chia seed shows good protein quality, hypoglycemic effect and improves the lipid profile and liver and intestinal morphology of wistar rats. Plant Foods for Human Nutrition, 71(3), 225-230. http://dx.doi.org/10.1007/s11130-016-0543-8. PMid:27193017.

Silva, M. O., Brigide, P., \& Canniatti-Brazaca, S. G. (2013). Caracterização da composição centesimal e mineral de diferentes cultivares de feijão comum crus e cozidos. Alimentos e Nutrição, 24, 339-346.

Singleton, V. L., Orthofer, R., \& Lamuela-Raventós, R. M. (1999). Analysis of total phenols and other oxidation substrates and antioxidants by means of folin-ciocalteu reagent. Methods in Enzymology, 299, 152178. http://dx.doi.org/10.1016/S0076-6879(99)99017-1.

Smiricky-Tjardes, M. R., Grieshop, C. M., Flickinger, E. A., Bauer, L. L., \& Fahey, G. C. Jr. (2003). Dietary galactooligosaccharides affect ileal and total-tract nutrient digestibility, ileal and fecal bacterial concentrations, and ileal fermentative characteristics of growing pigs. Journal of Animal Science, 81(10), 2535-2545. http://dx.doi. org/10.2527/2003.81102535x. PMid:14552381.

Stewart, M. L., \& Zimmer, J. P. (2018). Postprandial glucose and insulin response to a high-fiber muffin top containing resistant starch type 4 in healthy adults : a double-blind, randomized, controlled trial. Nutrition, 53, 59-63. http://dx.doi.org/10.1016/j.nut.2018.01.002. PMid:29655779.

Tako, E., Blair, M. W., \& Glahn, R. P. (2011). Biofortified red mottled beans (Phaseolus vulgaris L.) in a maize and bean diet provide more bioavailable iron than standard red mottled beans: studies in poultry (Gallus gallus) and an in vitro digestion/Caco-2 model. Nutrition Journal, 10(1), 113. http://dx.doi.org/10.1186/1475-2891-10-113. PMid:21995581. 
Tako, E., Reed, S., Anandaraman, A., Beebe, S. E., Hart, J. J., \& Glahn, R. P. (2015). Studies of cream seeded carioca beans (Phaseolus vulgaris L.) from a Rwandan efficacy trial: in vitro and in vivo screening tools reflect human studies and predict beneficial results from iron Biofortified beans. PLoS One, 10(9), 1-15. http://dx.doi.org/10.1371/ journal.pone.0138479. PMid:26381264.
Vaz-Tostes, M., Verediano, T. A., de Mejia, E. G., \& Brunoro Costa, N. M. (2016). Evaluation of iron and zinc bioavailability of beans targeted for biofortification using in vitro and in vivo models and their effect on the nutritional status of preschool children. Journal of the Science of Food and Agriculture, 96(4), 1326-1332. http://dx.doi. org/10.1002/jsfa.7226. PMid:25899136. 
Dias et al.

\section{Supplementary Material}

Supplementary material accompanies this paper.

Table S1. Food Composition and caloric density of experimental diets (g.100-1).

Table S2. Total food consumption, weight gain and food efficiency ratio (FER).

This material is available as part of the online article from http://www.scielo.br/IDSCIELO 